\title{
UDC 330.004.9
}

INFORMATION SOFTWARE PROVIDING EFFECTIVE ACTIVITY OF MACHINE-BUILDING ENTERPRISES OF UKRAINE IN RESOURCES RESTRICTIONS

\author{
ІНФОРМАЦІЙНЕ ЗАБЕЗПЕЧЕННЯ ЕФЕКТИВНОСТІ ДІЯЛЬНОСТІ \\ МАШІНОБУДІВНИХ ПІДРИСМСТВ УКРАЇНИ В УМОВАХ РЕСУРСНИХ \\ ОБМЕЖЕНЬ
}

\author{
Chuprina M.O. / Чупріна M.O.
} Ph.D., assistant prof. / к.е.н., доиент ORCID: 0000-0002-3276-4473

National Technical University of Ukraine «Igor Sikorsky Kyiv Polytechnic Institute», Kyiv Національний технічний університет Украйни «Київський політехнічний інститут імені Ігоря Сікорськог», м. Київ

Tolbatov A.V. / Толбатов A.B. Ph.D., assistant prof. / к.т.н., доиент ORCID: 0000-0002-9785-9975

Viunenko O.B. / В'юненко О.Б. Ph.D., assistant prof. / к.е.н., дочент ORCID: 0000-0002-8835-0704

Sumy National Agrarian University, Sumy, 160 Herasym Kondratiev, Sumy, 40021 Сумський національний аграрний університет, Суми, вул. Герасима Кондратьєва, 160, 40021

Tolbatov V.A. / Толбатов B.A. Ph.D, assistant prof. / к.m.н., доu. ORCID: 0000-0002-6564-9658

Sumy state university, Sumy, Rymskogo-Korsakova 2, 40007 Сумський державний університет, м. Суми, Римського-Корсакова 2, 40007

\begin{abstract}
It is determined that in the conditions of the resource constraints and the diversity of transformations within the national economic system, there is a need to expand the capacity and efficiency of domestic industrial enterprises, in particular, the machine-building industry. It is noted that using modern information technologies in the activities of enterprises and in the machinebuilding industry is a prerequisite for improving the efficiency of their work. It is emphasized that the experience of developed countries shows that the rapid development of information technologies manifests itself in the strengthening of information provision in economy and management, as well as in the constant diversification of the information sector. It is substantiated that it is vital to establish a multi-criterion approach in order to evaluate the effectiveness of the activity of the enterprise. Detailed key areas for improving economic effectiveness of the activity of the domestic companies and found that in terms of resource constraints important precondition is increasing effectiveness of the activity of the engeneering business enterprise is tehnical refit of companies, innovation activation of the activity, increase of productive work, development of the industrial infrastructure, of course, due to the intensification processes of building up the information of potential and practical use of third-level intellectual technologies, which could not only handle database, but formalize and analyze them. It has been established that the system of information improvement of the efficiency of domestic machine-building enterprises should have such an objective function that would relate to the goals of functioning of the economic system with the means of their achievement. It is noted that improvement of the information supports a process of domestic enterprises of the machine-building industry, above all, should be based on the implementation of modern software. It is proved that among the significant problems of informational support of the effictive activity of machine-building enterprises of Ukraine, one can
\end{abstract}


be distinguished: insufficient material and technical and software for creation of automated information resource management systems; absence of well-formed communication channels of information resources traffic in the internal environment of the enterprise for the adoption and implementation of management decisions; an imperfect mechanism for distributing information resources according to the needs of different levels of managerial staff, which leads to the disorganization of valuable information and inhibits the decision-making process. The indexes of estimation of the e-functionality of functioning of modern information systems are offered.

Key words: efficiency of activity, information sustainability improvement activity, information technologies, information management systems.

Formulation of the problem. Issues of ensuring the effectiveness of activities have always been one of the key places in the management system of entrepreneurship. Moreover, the expansion of the various policies and methods of achieving different results of activities in the conditions of the resource constraints and the diversity of transformations within the national economic system makes it unnecessary to search for new directions of activity, since the needs of the population are changing, so that the changes and outcomes are competitive more or less. The progress of the economy today is largely determined by advanced information technologies. It is the use of modern information technology in the enterprises of the machine-building industry is a prerequisite for improving the efficiency of their work. The experience of developed countries shows that the rapid development of information technology manifests itself in the strengthening of information provision in the economy and management, as well as in the constant diversification of the information sector [1], [2], [3], [4], [5], [6], [7].

Analysis of recent research and publications. In addition, the range of issues related to the information protection of the efficiency of domestic enterprises is discussed in the writings of such scholars as I. Bosak, G. Vasiliev, M. Denisenko, N. Ivlev, A. Klepikova, I. Kolos, P. Lizunov, , E. Paliga, V. Chernyavskaya. However, the use of the latest tools and information systems poses new issues that have not yet been thoroughly studied. The principle in the analysis of the given problem from the sub-headings is that in the same way the interpretation of the effect is effective so that the discrepancy is clearly defined. Despite a large number of scientific works, significant progress in the theory and practice of identifying of applied applications to improve the effectiveness of the business in the context of resource constraints is the need to find ways to most rational use and effective implementation of the information itself in the activity of the engeneering enterprises.

Purpose. The article is a theoretical substantiation of the directions directed at the integration of information technologies in the process of improving the efficiency of the activity of machine-building enterprises in conditions of resource constraints.

Presentation of the main research materials. It should be noted that the implementation of economic activity in terms of resource constraints require domestic enterprises to take active steps to improve the efficiency of their functioning. From the beginning of the development of economic science, the problem of effective functioning of business has come to the fore and remains relevant and timely. It is mechanical engineering that remains the basic industry of Ukraine, which determines the stable functioning and sustainable development of the national economy. Consequently, the assessment of the effectiveness of the 
operational activities, management decisions, the cost of the ecological processes, as well as the application of specific technologies and technologies to ensure the effective functioning of the engineering industry enterprises, are a great interest both to scientists and to economists.

More than one author fluencing the definition of effectiveness [5] understands this category as an effect (result) of the cost or resources that have been spent on its abstinence. Therefore, the criterias for effective action are based on the expense and resourceful approaches. The expense approach shows the effect of the accumulated expenditures of each unit of the individual expenditures of the life or embodied labor. A resourceful approach is called to characterize the effective use of resources: labor, material, financial. From other position [6] considers effectiveness: as its criterion, it determines the achievement of the established goals. In our opinion, the function of achieving the goal is important in determining the economic efficiency; It does not contradict the expense (resourceful) of the takeover to determine the effectiveness, has a more complex character, and, consequently, another method of calculation.

In the conditions of the resource constraints, according to the authors, it will be legal to use a multicriterial approach to the cost of effective operation of the enterprise, since the definition of the goals of its activities have multi-aspect nature. At the same time, determining of the effective operation of the business enterprise will exceed the limits of its indexes, as the functioning of the enterprise influences the behave of other market players. It seems that, in such a way, the whole model of the valuation is effective activity of the enterprise, according to which effectiveness is being considered at the five interrelated so-called pointas of view: repositioning of needs of interested people (which are the main participants of the programs of the project, on which they work and what needs they have); the contribution of interested people (which the company desires and needs from interested parties on a mutually advantageous basis); innovation strategies (which innovation strategies need to be scrutinized for those who want to reassure the needs and interests of interested sides, taking into account their own interests); procesess (which businesses need to be set up to implement strategies); opportunities (which may be necessary for the management of business interests). Among the areas of increasing the economic efficiency of operations at the level of machine-building enterprises, which are separated by scientists [5], [6], in the conditions of resource constraints, in our opinion, the development of industrial infrastructure has a particular importance (Fig. 1). It should be noted that in the opinion of the scientists, for mechanical engineering, for the effective implementation of the activities of enterprises an important precondition is the technological re-equipment of enterprises, the activation of the investment activity, the increase of labor productivity, the development of infrastructure, which, of course, is due to the intensification of the processes of information capacity building and the practical use of third-level intellectual technologies that allow not only to process databases, but also to formalize and analyze them. According to the authors, in the conditions of resource constraints, the system of informational improvement in the efficiency of domestic machine-building enterprises should have such a functional purpose that would closely associate the entire functioning of the economic system with the means of their achievement. The 
purpose of the information support of any company's activity is to obtain processed, aggregated information based on the collected data, which should be the basis for making managerial decisions.

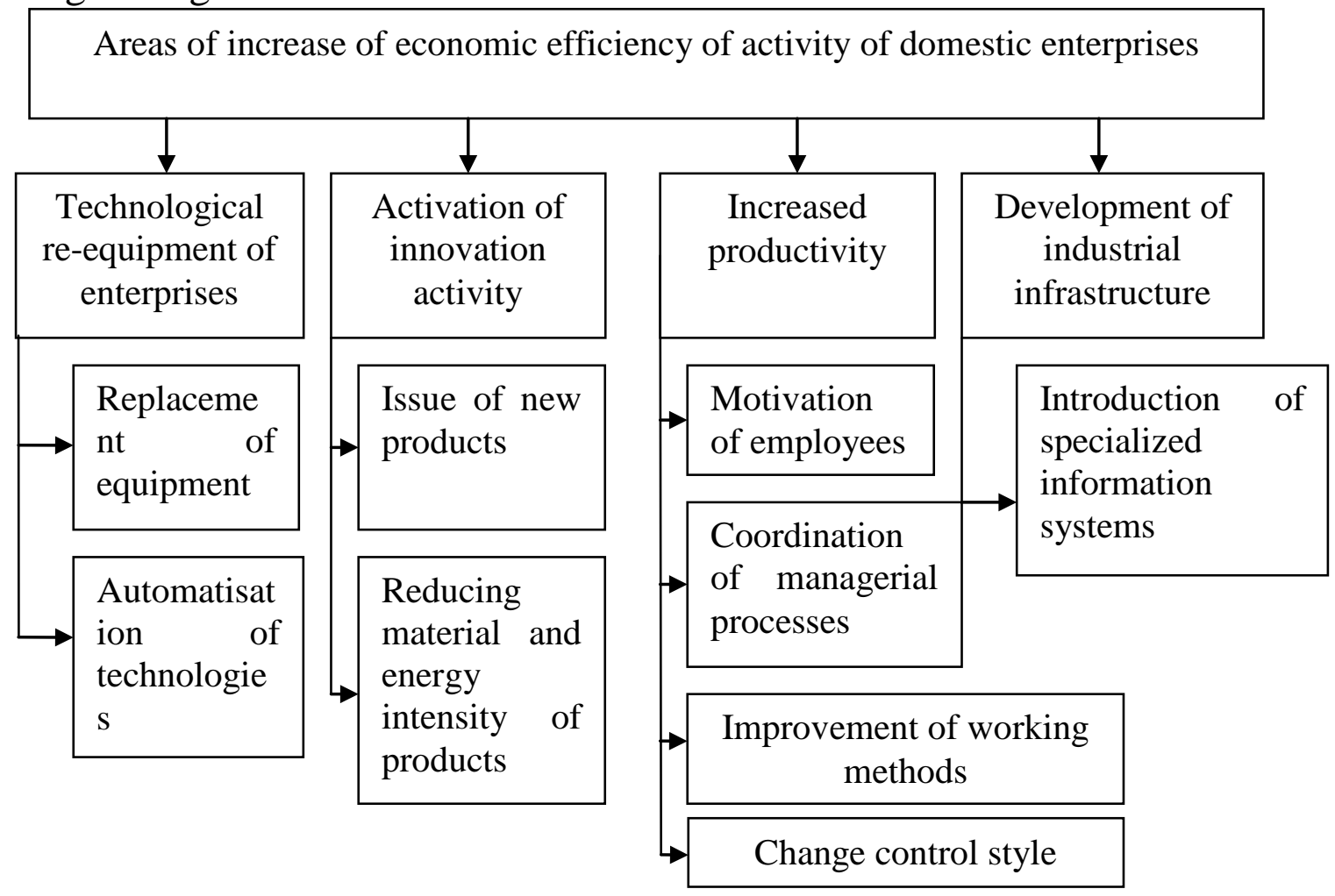

Fig. 1. Areas of increasing the economic efficiency of enterprises

This will allow directing the pace of accumulation of information resources on the effective solution of the following tasks: development of a new automated level of cost accounting, starting with the analysis of the costs of these costs and the possibility of adaptive management of them (for example, control and debt management, penetration into all costs of the organization and their analysis);

introduction of modern complex information systems for replacing the existing information protection, if it provides a separate, isolated information source and quickly becomes obsolete and meets the needs for efective management; focusing on consumers, both in terms of product and service redesign, both in terms of service provision; efeactivity, flexibility, adaptability to changes in the organization's activities; the use of such systems of application software, which, with the continuous development, allows the organization to adapt flexibly to changes in the market situation; the possibility of an integrated representation of all activity in dynamics; the possibility of merging into a single informational technological basis of economic and technical processes; creation of unified information streams; prevention of overcoming the variety of work done; automation of routine and hard work, which allows you to free at this workforce to perform more qualified tasks; the possibility of "one-click" button to provide relevant information to the government, not only for the adoption of not only opiative, but also important strategic decisions; the possibility of conducting a virtual analysis of the economic situation, with the aim of increasing the eefective control; the concentration of information that is not necessary for the adoption of operational and strategic decisions, in a single information space, which 
should become the driving force behind the work, optimization of economic oppression. Thus, informational support for the effectiveness of the enterprise can be represented by a set of unified system of indicators: - flows of information - variants of organization of document circulation - systems of classification and coding of information; - unified documentation system - various information arrays (files) stored in a machine and on carriers with different degrees of organization. The improvement of the information support process for domestic enterprises in the machine-building industry should be based, first of all, on the implementation of modern software, which can be classifiable depending on the specifics of the enterprise's activities [7].

Computer information systems (CIS) [1], [2], [3], [4], [5], [6], [7]. The most relevant today are "1C: Enterprise" and corporate information systems (KIS) of the class ERP (enterprise resource planning); software products of the DBMS class (object-oriented database management systems: PostgreSQL, Oracle, Microsoft SQL, Access, Sybase, MySQL, mSQL, etc. The most popular, both in Ukraine and abroad, in the practice of insurance, are the products of the developer Oracle - Oracle Insurance); program products for business processes (business process management BPM). As an example, the software of this group can be attributed a client-oriented strategy - CRM (Customer Relationship Management - Customer Relationship Management); DocFlow (document routing systems) and WorkFlow (workflow management systems) software; modeling and analyzing business processes of an insurance company. Products of this class are based on the application of modern computer simulation technology.

Among the significant problems of information support of the efficiency of the machine-building enterprises of Ukraine, it can be noted: insufficient logistical and software for the creation of automated information resource management systems; absence of well-formed communication channels of information resources traffic in the internal environment of the enterprise for the adoption and implementation of management decisions; an imperfect mechanism for distributing information resources according to the needs of different levels of managerial staff, which leads to the disorganization of valuable information and inhibits the decision-making process. The solution of these problems can be effectively implemented through the introduction of a well-formed information system in the management of the enterprise. It is the use of automated information systems to allow: improve time management characteristics; accelerate the process of information resources processing and provide control over the management process based on changes in the use and organization of work with information resources; considerably reduce the managerial staff of the enterprise, which is engaged in work on collecting, recording, storing and processing information resources; quickly, qualitatively and reliably fulfill the receipt, registration, storage and processing of information resources of the enterprise; to provide management and management personnel of the enterprise with the qualitative information at the right time; coordination of actions, which are achieved through the rapid access to the necessary information within the enterprise.

As regards the estimation of the efectiveness of the functioning of modern information systems, according to the authors, take into account the following 
indicators [4]: system performance, calculated by the time of response or the definite bandwidth; system flexibility, which is judged by the foreseeable modifications of the information system in accordance with the possible changes in the organization; readiness of the systems to the interaction, determined by the rules of access for the review and correction of information; the level of satisfaction of users, which is determined by a full set of useful functions; the efectiveness of the functioning of the information system, based on modern system analysis, spatial methods of provision and access to information, achievement of the given level of data bases.

Conclusions. Thus a new level of complex research of the phenomenon of analysis of information resource the transformation of machine-building enterprises, the meaning of the latter in the context of social change is connected with the disclosure of the reasons for its special role in the modern stage of socioeconomic program, with the advent to innovative modes of development and the need of protection of a sufficient level of economic security. The effectiveness of the adoption of administrative decisions and increase their substantiation, in the context of the innovative activity of domestic machine-building enterprises, is impossible without the improvement of information security by the means of the digitization of the information of the enhancement of the efective using of it.

The elements of scientific novelty include the justification of the directions of reducing the information support of the effectiveness of machine-building enterprises in terms of resource constraints by taking into account the degree of response to changes in the environment, development of business measures to minimize the impact of crisis fact on the efficiency of co-ordination. Prospects for scientific developments in this area should be aimed at developing recommendations for the practical implementation of modern information systems and technologies to improve the efficiency of enterprises in terms of resource constraints.

\section{Literature:}

1. Tolbatov A. Using cloud technologies based on intelligent agent-managers to build personal academic environments in E-learning system / Agadzhanova, S., Tolbatov, A., Viunenko, O., Tolbatova, O. / 2017 2nd International Conference on Advanced Information and Communication Technologies, AICT 2017 - Proceedings - Lviv, 2017. - P. 92-96.

2. Tolbatov, A. Theoretical bases, methods and technologies of development of the professional activity analytical estimation intellectual systems / Zaritskry, O., Pavlenko, P., Sudic, V., Tolbatov, A., Tolbatova, O., Tolbatov, V., Viunenko, O. / 2017 2nd International Conference on Advanced Information and Communication Technologies, AICT 2017 - Proceedings - Lviv, 2017. - P. 101-104.

3. Tolbatov A.V. Business processes management at machine-building enterprise / A.V. Tolbatov, O.O. Tolbatova, I.A. Shekhovtsova, V.A. Tolbatov // International scientific-technical magazine Measuring and computing devicesin technological processes. - Khmel'nyts'kyy, 2017. №4 -P. 119-124.

4. Tolbatov A.V. Functional modeling - methodological basis for invertigation of business processes at indusrtial enterprises / A.V. Tolbatov, S.V. Tolbatov, O.O. Tolbatova, V.A. Tolbatov // Magazine Measuring and computing devicesin technological processes. - Khmel'nyts'kyy, 2017. - №3 - P.186-189.

5. Tolbatov, A. Cybersecurity of distributed information systems. The minimization of damage caused by errors of operators during group activity / Lavrov, E., Tolbatov, A., Pasko, N., Tolbatov, V. / 2017 2nd International Conference on Advanced Information and Communication 
Technologies, AICT 2017 - Proceedings - Lviv, 2017. - P. 83-87.

6. Tolbatov A. Data Representing and Processing in Expert Information System of Professional Activity Analysis / Oleh Zaritskiy, Petro Pavlenko, Andrii Tolbatov // TCSET 2016 Lviv-Slavske, 2016. - P. 718-720.

7. Tolbatov A. Mathematical models for the distribution of functions between the operators of the computer-integrated flexible manufacturing systems / Evgeniy Lavrov, Nadiia Pasko, Anna Krivodub, Andrii Tolbatov // TCSET 2016 - Lviv-Slavske, 2016. - P. 72-75.

Анотація. Визначено, щзо в умовах ресурсних обмежень та різноманітності трансформачій в межах начіональної економічної системи виникає потреба розширення можливостей $і$ методів забезпечення ефективності діяльності вітчизняних промислових підприємств, зокрема машинобудівної галузі. Зазначено, щчо саме використання сучасних інформаційних технологій у діяльності підприємств машинобудівної галузі є необхідною умовою підвищення ефективності їх роботи. Підкреслено, щзо досвід країн з розвинутою економікою свідчить, щзо стрімкий розвиток інформаційних технологій проявляється в посиленні інформаційного забезпечення в економіиі й управлінні, а також у постійній диверсифікованості інформаційного сектора. Обгрунтовано зочільність застосування багатокритеріального підходу до оцінки ефективності діяльності підприємства. Деталізовані ключові напрями підвищення економічної ефективності діяльності вітчизняних підприємств та встановлено, щзо в умовах ресурсних обмежень, важливою передумовою зростання ефективності діяльності мвшинобудівниз підприємств $\epsilon$ технологічне переозброєння підприємств, активізачія інноваційної діяльності, підвищення продуктивності прачі, розвиток виробничої інфраструктури, щзо безумовно, пов'язано із інтенсифікацією прочесів нарощення інформаційного потенціалу та практичного використання інтелектуальних технологій третього рівня, які дозволяють не лише обробляти бази даних, а також формалізувати та аналізувати їх. Встановлено, щзо підсистема інформаційного забезпечення ефективності діяльності вітчизняних машинобудівних підприємств повинна мати такий цільовий функціонал, який би щільно пов'язував иіілі функціонування економічної системи із засобами їх досягнення. Зазначено, щуо удосконалення прочесу інформаційного забезпечення діяльності вітчизняних підприємств машинобудівної галузі, перш за все, повинно базуватися на впровадженні сучасного програмного забезпечення. Доведено, щзо серед суттєвих проблем інформаційного забезпечення ефективності діяльності машинобудівних підприємств України, можна виділити: недостатнє матеріально-технічне та програмне забезпечення для створення автоматизованих систем управління інформаційними ресурсами; відсутність чітко сформованих комунікаційних каналів руху інформаційних ресурсів у внутрішньому середовищі підприємства для прийняття та реалізації управлінських рішень; недосконалий механізм розподілу інформаційних ресурсів відповідно до потреб різних рівнів управлінського персоналу, щзо призводить до дезорганізації ичінної інформаиї̈ та гальмує процес прийняття рішень. Запропоновано показники оцінювання ефективності функціонування сучасних інформаційних систем.

Ключові слова: ефективність діяльності, підсистема інформаційного забезпечення ефективності діяльності, інформаційні технології, інформаційні системи менеджменту. 